\title{
Investigating the Antibacterial Activity of POMA Nanocomposites
}

\author{
Altaf Hussain ${ }^{1}$, Mirza Nadeem Ahmad ${ }^{2}$, Fatima Jalal ${ }^{3}$, Muhammad Yameen ${ }^{4}$, \\ Sadia Falak ${ }^{5}$, Saima Noreen ${ }^{6}$, Saima Naz ${ }^{7}$, Arif Nazir ${ }^{8 *}$, Shan Iftikhar ${ }^{8}$, \\ Gul Afshan Soomro ${ }^{9}$, Munawar Iqbal ${ }^{8}$ \\ ${ }^{1}$ Department of Chemistry, Government College University Faisalabad, Pakistan \\ ${ }^{2}$ Department of Applied Chemistry, Government College University, Faisalabad, Pakistan \\ ${ }^{3}$ Department of Zoology, Government College University, Faisalabad, Pakistan \\ ${ }^{4}$ Department of Biochemistry, Government College University, Faisalabad, Pakistan \\ ${ }^{5}$ School of Pharmacy, The University of Faisalabad, Faisalabad, Pakistan \\ ${ }^{6}$ Department of Chemistry, University of Agriculture, Faisalabad, Pakistan \\ ${ }^{7}$ Institute of Chemical Sciences, Bahauddin Zakariya University, Multan, Pakistan \\ ${ }^{8}$ Department of Chemistry, The University of Lahore, Lahore, Pakistan \\ ${ }^{9}$ Institute of Chemistry, Shah Abdul Latif University, Khairpur, Sindh, Pakistan
}

Received: 16 January 2018

Accepted: 3 July 2018

\begin{abstract}
In this study, antibacterial activity of the prepared nanocomposites [poly (o-methoxy-aniline); POMA] at different concentrations was tested on bacterial strains. Nanocomposites were prepared by in situ chemical polymerization of ortho anisidine monomer in acidic medium with ammonium peroxydisulphate (APS) as an oxidant. The composition, structure and morphology of the polymer and nanocomposites were characterized by Fourier transform infrared spectroscopy (FTIR), x-ray diffraction (XRD) and ultraviolet-visible (UV-vis) spectroscopy. Different concentrations of nickel nanoparticles $(1 \%, 2 \%, 3 \%, 4 \%, 5 \%)$ were used to confirm the characteristics of the synthesized nanocomposites. Antibacterial activity was tested against two strains: E. coli and S. typhi. A significant increase in the antibacterial activity of nanocomposites has been observed with an increase in concentration of nickel nanoparticles (Ni NPs). Excellent antibacterial activity was observed with nanocomposite having 5\% Ni NPs.
\end{abstract}

Keywords: Poly (o-methoxy aniline); nanocomposites; nanoparticles; antibacterial activity; polymerization

*e-mail: anmalik77@gmail.com 


\section{Introduction}

Nanotechnology is the drawing, fabrication, classification and application of structures, devices and systems by calculating the size and form at the nanometre level [1-2]. Nanotechnology is the recognized powerful tool to explain the deepest and darkest track of medical science in different ways, such as targeted drug delivery, sensing, imaging, and artificial implants. The modern age drugs are made up of NPs from polymers, ceramics or metals that can fight against cancer and combat human pathogens such as bacteria [3-4]. The nanomaterials have a variety of applications employed nano-filtration, adsorbents of poisonous compounds and biomaterials [5]. The nanomaterials can be prepared by hybridization of organic and inorganic materials, and these hybrid materials can combine the usual heterogeneous properties of both the components [6-7]. The conducting polymer is among the significant and capable new group of materials that are being exercised for many purposes [8-9].

Polyaniline and poly (o-anisidine) have been widely studied for such devices, which are run by solar energy due to their photo electrochemical properties. Polyaniline is commonly known as the most stable material through the class of conducting polymers. The methoxy group $\left(-\mathrm{OCH}_{3}\right)$ is responsible for torsional angle between o-anisidine and aniline rings, which exhibits better electro chromic properties as compared to polyaniline. The solubility of poly (o-anisidine) was improved within organic solvents by a substituted methoxy group. Nevertheless, the conductivity of poly (o-anisidine) was decreased by increasing the side group [10-16].

In recent years the most important and significant nano product in the nanotechnology field is silver NPs, which are widely and significantly used in textiles and garments, food covering, medicinal and cosmetic raw material, fresh water, wastewater and to treat air, pesticides and also in domestic usage [17-24]. Ni NPs have shown excellent antibacterial properties against Escherichia coli, Lactobacillus casei, staphylococcus aureus, Pseudomonas aeruginosa and Bacillus subtilis [25-26]. At present, nanocomposites offer new business opportunities for all areas of technology and industry in spite of being conservational and green in nature [27-30]. The inclusion of the substituent in the polymer framework is one of the common methods to produce polymers with better properties. The main objective of the current study is therefore to grab an opportunity by choosing the poly (o-anisidine) as substitute to polyanilines for investigating antibacterial activity.

\section{Materials and Methods}

The main reagents include o-methoxy aniline monomer, APS (Merck), Hydrochloric acid ( $\mathrm{HCl})$, Nitric

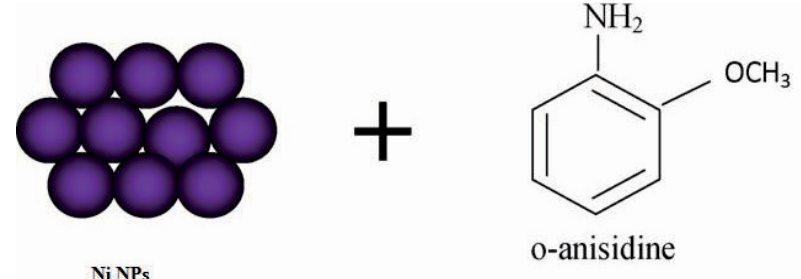

NiNPs

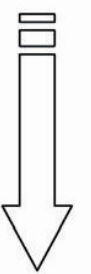

$\mathrm{HCl},\left(\mathrm{NH}_{4}\right)_{2} \mathrm{~S}_{2} \mathrm{O}_{8}, \mathrm{H}_{2} \mathrm{O}$

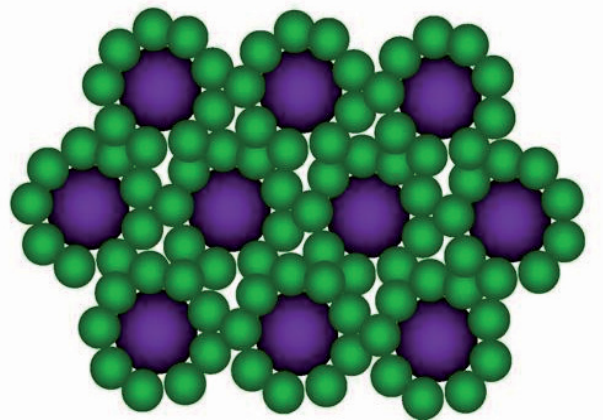

Fig. 1. Schematic diagram of the formation mechanism of POMA-Ni nanocomposite.

acid $\left(\mathrm{HNO}_{3}\right)$ and 2, 4-diaminodiphenylamine - all of analytical grade.

The POMA conducting polymer was polymerized by the chemical oxidative polymerization techniques. $3 \mathrm{~g}$ of o-anisidine was dissolved in $10 \mathrm{ml}$ of $1 \mathrm{M}$ hydrochloric acid and cooled between 0 and $4^{\circ} \mathrm{C}$. Later, a solution of $4 \mathrm{~g}$ ammonium persulphate in $10 \mathrm{ml}$ of 1 $\mathrm{M}$ hydrochloric acid was added slowly to the o-anisidine solution. The reaction mixture was stirred continuously for 12 hours in an ice bath and the dark green precipitates of the polymer were filtered and washed using deionized water and methanol to remove the oligomers and other impurities. The filtered POMA conducting polymer was dried in an oven at $80^{\circ} \mathrm{C}$ for 2 hours.

A similar experimental procedure was followed to synthesize the POMA/Ni nanocomposites, except when adding Ni NPs at different ratios to the monomer (o-anisidine). First of all, $3 \mathrm{~g}$ of o-anisidine in $10 \mathrm{ml}$ of $1 \mathrm{M} \mathrm{HCl}$ solution was stirred for 2 hours and Ni NPs were mixed in the solution in different percentages $(1 \%, 2 \%$, $3 \%, 4 \%, 5 \%$ ). Then the resulting solution was stirred for 30 minutes in an ice bath. The polymerization started after the addition of APS into the mixture solution of o-anisidine and Ni NPs. The reaction mixture was stirred continuously for 12 hours in an ice bath and the resulting product was filtered and washed using deionized water and methanol to remove the oligomers and other impurities, and filtrate was dried in an oven at $80^{\circ} \mathrm{C}$ for 120 minutes. Paper discs of $6 \mathrm{~mm}$ diameter were prepared from Whatman filter paper. Different 
dilutions of NPs were taken and 100 microliter water was added to make a suspension. 10 microliter of each suspension was added to each disc.

$3.4 \mathrm{~g}$ of Mueller Hinton (MH) agar was taken in a flask and $100 \mathrm{ml}$ of distilled water was added to it, and $\mathrm{pH}$ was adjusted to neutral. The flask was covered and autoclaved. $20 \mathrm{ml}$ of this media was poured into a petri dish. (1 liter on $\mathrm{MH}$ agar contains $30 \%$ beef infusion $1.75 \%$ casein hydrolysate, $0.15 \%$ starch and $1.7 \%$ agar). 5 grams of MacConkey agar powder was taken in a flask. $100 \mathrm{ml}$ of distilled water was added to it. The $\mathrm{pH}$ was adjusted to 7.1. The flask was covered and autoclaved. $20 \mathrm{ml}$ of media was poured into a petri dish. (1 liter of MacConkey agar contains peptone - $17 \mathrm{~g}$, protease peptone $-3 \mathrm{~g}$, lactose - $10 \mathrm{~g}$, bile salts - $1.5 \mathrm{~g}$, sodium chloride - $5 \mathrm{~g}$, neutral red $0.03 \mathrm{~g}$, crystal violet - $0.001 \mathrm{~g}$, agar $13.5 \mathrm{~g}$, water - add to make 1 liter; adjust $\mathrm{pH}$ to $7.1+/-0.2$ ).

The optical absorption spectrum of the prepared POMA/Ni nanocomposite were measured in the UV-vis range (200-800 $\mathrm{nm}$ ) with a Agilent 8454 singlebeam shimadzu UV-1800 double beam. FTIR analyses of POMA/Ni nanocomposite were recorded with an Agilent 630 spectrometer. The FTIR spectrum of pure polymer and nanocomposite samples were recorded and assignments of absorption peaks were discussed. FTIR spectroscopy is basically a useful tool and technique for estimation and to understand the functional group of any of the organic molecules.

The antibacterial test was performed by the standard disc diffusion method. Nutrient broth/agar was used to cultivate the bacteria. MacConkey agar was used for gram negative bacteria Escherichia coli (E. coli) only. E. coli can grow on MacConkey but Salmonella Typhi (S. typhi) cannot grow on MacConkey, so MH media was used for S. typhi. The media were autoclaved and then cooled. The media were poured into petri plates for 40 minutes. After 40 minutes, the fresh inoculum $(20 \mathrm{ml})$ of bacteria cultures were spread on to solidified agar plates. Bacterial cultures were collected from UVAS university diagnostic lab. Sterile paper discs

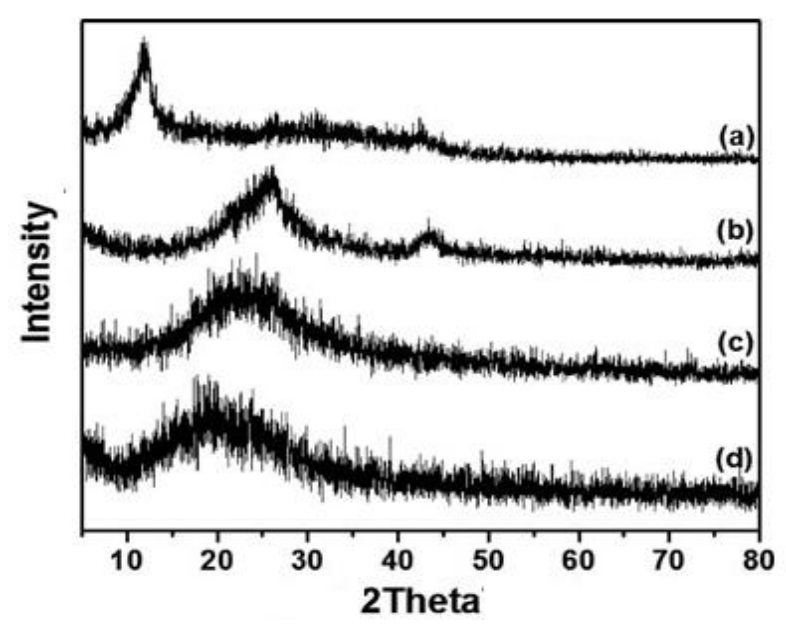

Fig. 2. XRD pattern of synthesized nanomaterial (POMA). dipped in different dilutions of Ni nanocomposites were placed in every plate. The agar plates were incubated at $37^{\circ} \mathrm{C}(310 \mathrm{~K})$ for $24 \mathrm{~h}$. After $24 \mathrm{~h}$ of incubation, the zones of inhibition were investigated. Sensitivity test consideration for the sensitivity and resistance of bacteria were based on the extent of the presence or absence zones of growth inhibition, respectively.

\section{Results and Discussion}

The XRD pattern of the prepared POMA and POMA/Ni nanocomposite is shown in Fig. 2. The pattern shows the broad diffraction peaks at $2 \theta$ around $7.8^{\circ}$ and $23.6^{\circ}$, which are attributed to the periodicity perpendicular to the polymer chains of POMA. In the case of POMA/Ni nanocomposites, the diffraction pattern shows the broad peak in the range from $16-27^{\circ}$, which may be attributed to the characteristic peaks of POMA and Ni nanocomposites.

The broad peaks were successfully calculated from diffraction line by using Scherrer's equation, $L=k \lambda$ / $\beta \cos \theta$, whereas " $L$ " is the mean dimension of the crystallites, $\beta$ is the full width at half maximum of the diffraction peak, $\theta$ is the diffraction angle, $\lambda$ is the wavelength of the $\mathrm{Cu} \mathrm{K \alpha}$ radiation $(0.1540 \mathrm{~nm})$, and $\mathrm{K}$ is equal to 0.89 [22].

Fig. 3a) shows that the spectrum exhibits the poly 2-methoxy aniline features at $3380 \mathrm{~cm}^{-1}$, which is attributed to (N-H stretching mode), $1590 \mathrm{~cm}^{-1}(\mathrm{C}=\mathrm{C}$ stretching modes of quinoid ring), $1470 \mathrm{~cm}^{-1}(\mathrm{C}=\mathrm{C}$ stretchingmodes of benzenoid rings), $1205 \mathrm{~cm}^{-1}$ and $1030 \mathrm{~cm}^{-1}$ recognised to stretching vibration of orthomethoxy group, $950 \mathrm{~cm}^{-1}$ shows in-plane $\mathrm{CH}$ vibration of quinoid ring and $830 \mathrm{~cm}^{-1}$ shows ortho-substituted benzene ring. Thus the stretching vibrations of methoxy band in the spectrum clearly shows the presence of poly-2-methoxy aniline [23]. In Fig. 3b), the spectrum shows that by the addition of $1 \%$ Ni NPs in the polymer matrix the peak at $3510 \mathrm{~cm}^{-1}$ has become deep as well as wide, which illustrates that a $1 \%$ addition of Ni NPs has enhanced the crystallinity of the polymer.

Fig. 3c) displays that by the addition of $2 \%$ Ni NPs in the polymer matrix the peak at $3510 \mathrm{~cm}^{-1}$ is almost same as in $1 \%$, which illustrates that $2 \%$ addition of $\mathrm{Ni}$ NPs has enhanced the crystallinity of the polymer. The spectrum shows that by the addition of $2 \%$ Ni NPs in the polymer matrix the peak at $1627 \mathrm{Cm}^{-1}$ shows the binding of Ni NPs with polymer matrix. The peak at $1590 \mathrm{~cm}^{-1}$ is attributed to $(\mathrm{C}=\mathrm{C})$ stretching modes of quinoid ring. In Fig. 3d), the spectrum shows that by the addition of $3 \% \mathrm{Ni}$ NPs in the polymer matrix, the charcteristics peak was observed at $1248 \mathrm{~cm}^{-1}$, which illustrates that $3 \%$ addition of Ni NPs has enhanced the crystallinity of the polymer. The spectrum shows that by the addition of $3 \% \mathrm{Ni} \mathrm{NPs}$ in the polymer matrix the peak at 1627 $\mathrm{cm}^{-1}$ shows the binding of Ni NPs with polymer matrix. The peak at $1590 \mathrm{~cm}^{-1}$ is attributed to $(\mathrm{C}=\mathrm{C})$ stretching modes of quinoid ring. 

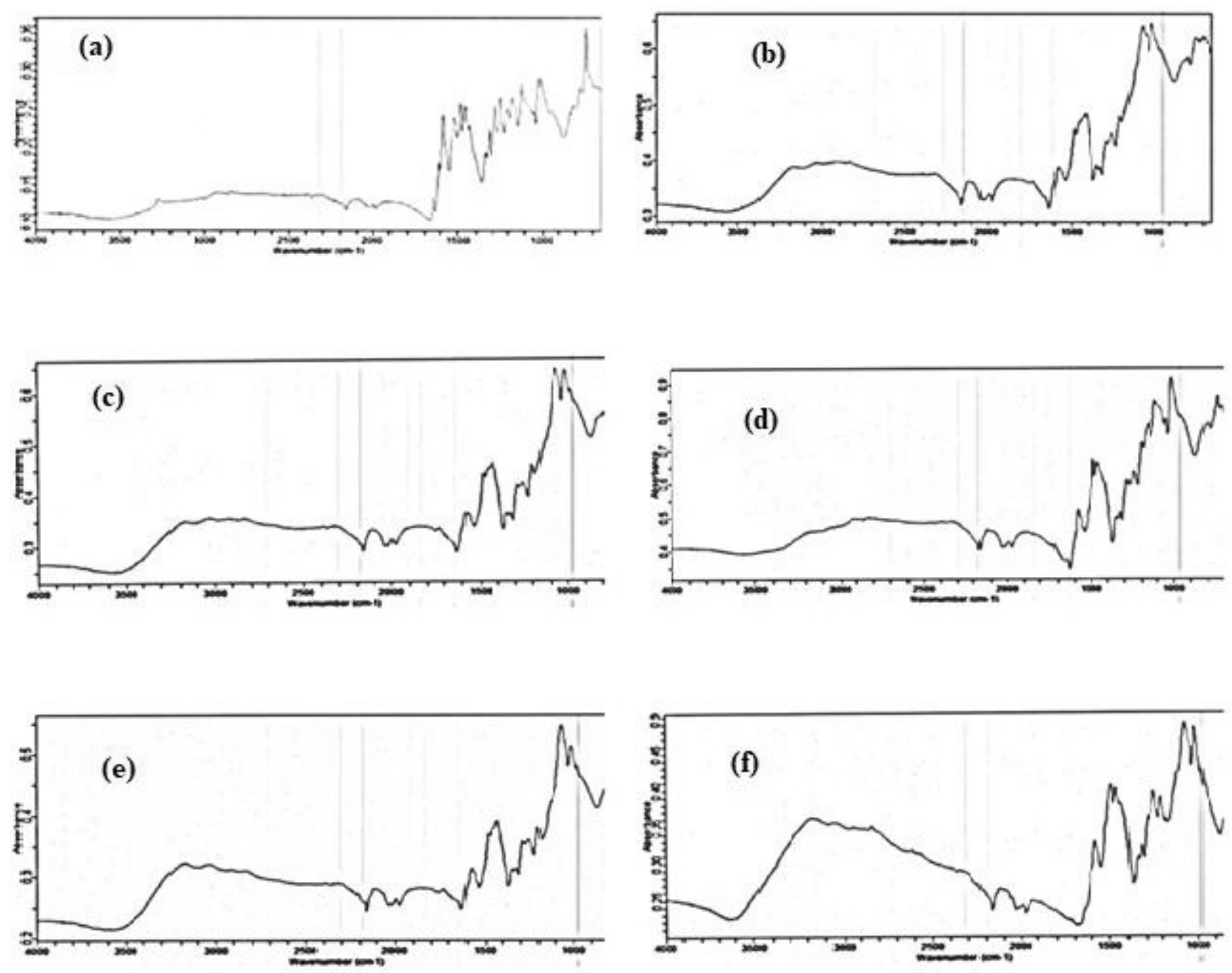

Fig. 3. FTIR spectrum of a) poly 2-methoxy aniline, b-f) synthesized nanomaterial by addition of 2-5\% Ni NPs to the polymer matrix.

In Fig. 3e), the spectrum shows that by the addition of $4 \% \mathrm{Ni}$ NPs in the polymer matrix, the peak at 3510 $\mathrm{cm}^{-1}$ was again observed, which is deep but not as wide as in the previous cases, which illustrates that $4 \%$ addition of Ni NPs has enhanced the crystallinity of the polymer. Furthermore, the spectrum shows that by the addition of $4 \%$ Ni NPs in the polymer matrix the peak at $1627 \mathrm{~cm}^{-1}$ shows the binding of Ni NPs with polymer matrix. The peak at $1590 \mathrm{~cm}^{-1}$ is attributed to $(\mathrm{C}=\mathrm{C})$ stretching modes of quinoid ring.

Fig. 3f) demonstrates the spectrum of $5 \%$ Ni NPs, and it can be seen that by the addition of $5 \%$ Ni NPs in the polymer matrix, the peak at $3510 \mathrm{~cm}^{-1}$ was sharp and deep comparitively, which illustrates that $5 \%$ addition of Ni NPs has enhanced the crystallinity of the polymer in a different way. Furthermore, the spectrum shows that by the addition of $5 \% \mathrm{Ni}$ NPs in the polymer matrix the peak at $1627 \mathrm{~cm}^{-1}$ shows the binding of Ni NPs with polymer matrix. The peak at $1590 \mathrm{~cm}^{-1}$ is attributed to $(\mathrm{C}=\mathrm{C})$ stretching modes of the quinoid ring.

UV-visible analysis of the synthesized poly o-anisidine as well its nanocomposites with the Ni NPs having different concentrations was performed. Very dilute solutions were used to study the absorbance of
$\mathrm{UV}$ radiation. The solvent used was $0.1 \mathrm{M} \mathrm{HCl}$. Benzene ring and $-\mathrm{NH}$ functional group is responsible for the absorbance of the radiation in the UV region.

In the pure sample a strong peak was observed at $273 \mathrm{~nm}$ with $87 \%$ absorbance. This is due to $\pi-\pi^{*}$ transitions of aromatic $\mathrm{C}=\mathrm{C}$ band and $\mathrm{n}-\pi^{*}$ transitions of $\mathrm{C}=\mathrm{N}$ band. The conjugation and planarity is due to the para attachment of anisidine monomers. With the addition of $1 \% \mathrm{Ni}$ NPs content there is no change in $\lambda_{\max }$, but absorbance decreased to $40 \%$, thus it can be observed with the addition of a very minute quantity of Ni NPs (1\%) as the absorbance decreases. It can be observed that with the increase of Ni NPs content from $1 \%$ to $2 \%$, there is no change in $\lambda_{\max }$, but it is quite evident that absorbance was further decreased to $36 \%$. It can be seen that with the addition of Ni NPs content up to $3 \%$, blue shift in $\lambda_{\max }$ (from 273-265 nm) observed was very small. The $\lambda_{\max }$ with $4 \%$ Ni NPs content was almost the same as with $3 \%$, but the main difference is in absorbance, which decreases sharply in absorbance (26\%). The nanocomposite having 5\% Ni NPs content was much more interesting, which dramatically recovered $\lambda_{\max }$ as for $0 \%, 1 \%$ and $2 \%$, but absorbance was up to $57 \%$. All results clearly indicate that there is a 


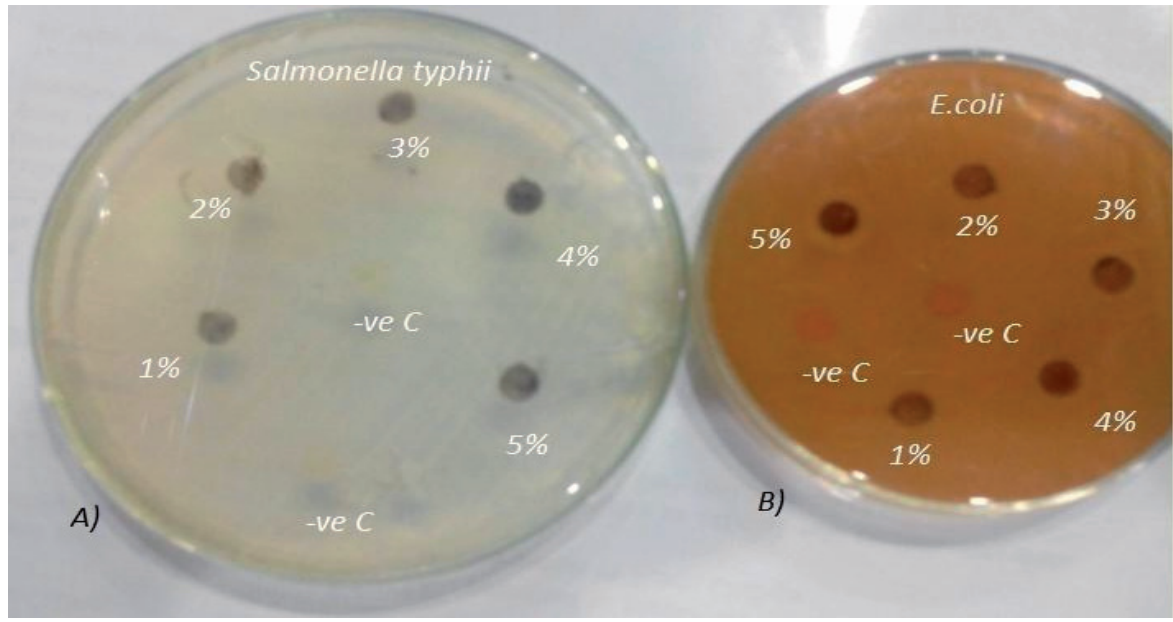

Fig. 4. Antimicrobial activity of POMA/Ni nanocomposites: A) the culture test against Salmonella typhi and B) the culture test against E. coli. In both images $-\mathrm{ve} \mathrm{C}=$ negative control.

strong interaction of Ni NPs content on the absorbance as well as on $\lambda_{\max }$ among all the synthesized samples.

No zone of inhibition was observed against $S$. typhi culture. This suggests that these nano-composites do not possess any growth inhibitory effect against $S$. typhi, as shown in Fig. 4a).

- No zone for 1 and $2 \%$ suspension on E. coli.

- $0.5 \mathrm{~cm}$ diameter of zone of inhibition for $3 \%$ on E. coli.

- $0.6 \mathrm{~cm}$ diameter of zone of inhibition for $4 \%$ on E. coli.

- $0.9 \mathrm{~cm}$ diameter of zone of inhibition for $5 \%$ on E. coli.

It was noticed that $5 \%$ was the optimum concentration of Ni NPs that inhibited the growth of E. coli (Fig. 4b). Ni NPs were found to be valuable antibacterial agent for gram negative bacteria (E. coli).

The huge surface area of NPs, in comparison to bulky particles, that is free for interactions increases their bactericidal effect, so NPs are more cytotoxic to the microorganisms. Although the method of NP penetration into bacteria is not known absolutely, studies have proposed that the treatment of bacterial culture with NPs causes changes in the membrane morphology of membrane, causing a considerable rise in its permeability, which in turn disturbs suitable transport through the plasma membrane. The bacterial cells have become unable to accurately regulate the transport through the plasma membrane, leading to cell death [31-40]. Fig. 5 shows the inhibition zone of POMA/Ni nanocomposites at various concentrations.

It is supposed that because of their small size, $\mathrm{Ni}$ NPs entered the bacterial cell membrane and attached to functional groups of proteins, causing their denaturation [41-47]. They are also thought to cause damage to the bacterial cell by reacting with compounds having phosphorous- and sulphur-like DNA11, resulting in the death of bacterial cells. The total bacterial inhibition is directly related to the concentrations of Ni NPs
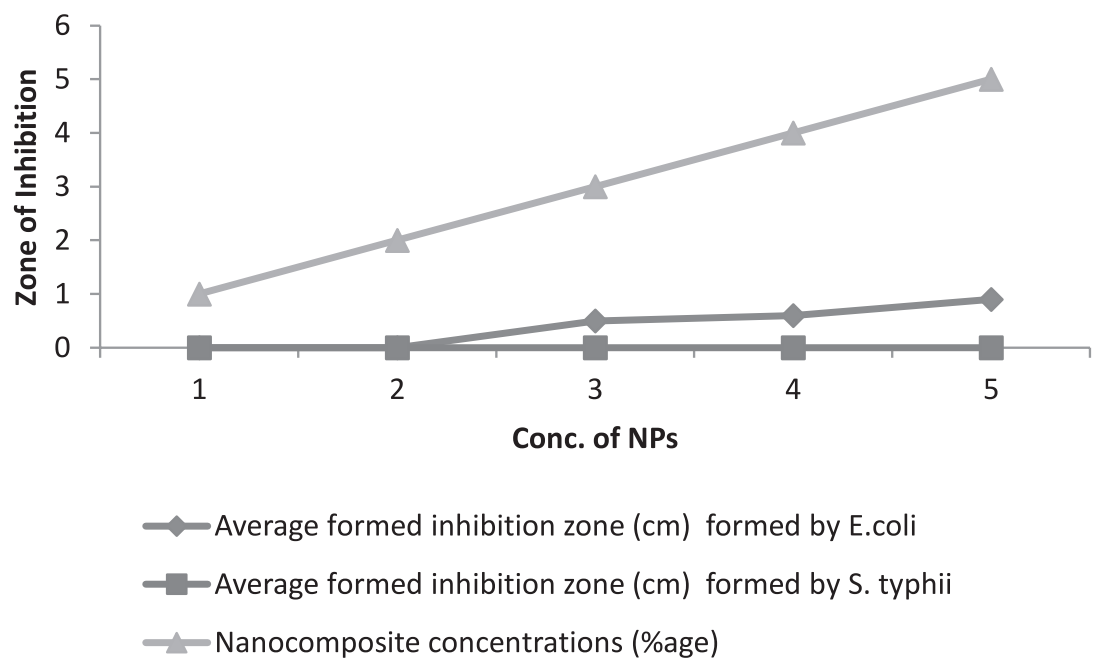

Fig. 5. Plot of inhibition zone versus various POMA/Ni nanocomposites at various concentrations of Ni NPs. 
and on the number of bacterial cells. This reveals that $\mathrm{Ni}$ NPs have considerable bactericidal effect in decreasing growth of bacteria for useful purposes [47-49]. Under the current scenario of environmental pollution [50-59], there is a need to develop photocatalysts for the remediation of pollutants, and NPs could possibly be used for this purpose.

\section{Conclusions}

A significant increase in the antibacterial activity of nanocomposites was observed with the increase in concentration of Ni NPs. Exceptional antibacterial activity was detected with nanocomposites having $5 \%$ Ni NPs. Thus, the in situ chemical oxidative polymerization technique can be easily and successfully applied for the preparation of many nanocomposites useful for antibacterial activities.

\section{References}

1. SHARMA Y.C., SRIVASTAVA V.K., MUKHERJEE A. Synthesis and Application of Nano- $\mathrm{Al}_{2} \mathrm{O}_{3}$ Powder for the Reclamation of Hexavalent Chromium from Aqueous Solutions. J. Chem. Eng. Data. 55, 2390, 2010.

2. CURTIS A., WILKINSON C. Nano-techniques and approaches in biotechnology. Trends Biotech. 19, 97, 2001.

3. SINGH M., SINGH S., PRASADA S., GAMBHIR I.S. Nanotechnology in medicine and antibacterial effect of silver nanoparticles. Dig. J. Nanomater. Biostruc. 3, 115, 2008.

4. SALAVATI-NIASARI M., SHATERIAN M., GANJALI M.R., NOROUZI P. Oxidation of cyclohexene with tert-butylhydroperoxide catalysed by host (nanocavity of zeolite-Y)/guest ( $\mathrm{Mn}(\mathrm{II}), \mathrm{Co}(\mathrm{II}), \mathrm{Ni}(\mathrm{II})$ and $\mathrm{Cu}(\mathrm{II})$ complexes of N,N'-bis(salicylidene) phenylene-1,3diamine) nanocomposite materials (HGNM). J. Mol. Catal. A: Chem. 261, 147, 2007.

5. KHAN A.A., KHAN A. Synthesis, characterization and electrical conductivity measurement studies of polyo-anisidine $\mathrm{Sn}(\mathrm{IV})$ phosphate [POASn(IV)P] nanocomposite cation-exchange material. Mater. Sci. Eng., B. 158, 92, 2009.

6. JUDEINSTEIN P., ANCHEZ C.S. Hybrid organicinorganic materials: a land of multidisciplinary. J. Mater. Chem. 6, 511, 1996.

7. RUIZ-HITZKY E., CASAL B., ARANDA P., GALVAN J.C. Inorganic-organic nanocomposite materials based on macrocyclic compounds. Rev. Inorg. Chem. 21, 125, 2001.

8. ROITER Y., MINKO S. AFM Single Molecule Experiments at the Solid-Liquid Interface: In Situ Conformation of Adsorbed Flexible Polyelectrolyte Chains. J. Am. Chem. Soc. 127, 15688, 2005.

9. SAVALE P.A., SHIRALE D.J., DATTA K., GHOSH P., SHIRSAT M.D. Synthesis and characterization of poly (o-anisidine) films under galvanostatic conditions by using ECP technique. Int. J. Electrochem. Sci. 2, 595, 2007.

10. MATTOSO LHC., BULHOES LOS. Synthesis and characterization of poly (o-anisidine) films. Synthetic Met. 52 (2), 171, 1992.

11. OZDEMIR C., CAN H.K., COLAK N., GUNER A. Synthesis, characterization, and comparison of self- doped, doped, and undoped forms of polyaniline, poly (o-anisidine) and poly [aniline-co-(o-anisidine)]. J. Appl. Polym. Sci. 99, 2182, 2006.

12. PATILA S., SAINKARB S.R., PATIL P.P. Poly (o-anisidine) coatings on copper: synthesis, characterization and evaluation of corrosion protection performance. Appl. Surf. Sci. 225, 204, 2004.

13. DARGAHI A., GOLESTANIFAR H., DARVISHI P., KARAMI A., HASAN SH., POORMOHAMMADI A., BEHZADNIA A. An Investigation and Comparison of Removing Heavy Metals (Lead and Chromium) from Aqueous Solutions Using Magnesium Oxide Nanoparticles. Pol. J. Environ. Stud. 25 (2), 557, 2016.

14. KOWALSKA-GÓRALSKA M., SENZE M., POLECHOŃSKI R., DOBICKI W., POKORNY P., SKWARKA T. Biocidal Properties of Silver-Nanoparticles in Water Environments. Pol. J. Environ. Stud. 24 (4), 1641, 2015.

15. BUBACZ K., CHOINA J., DOLAT D., MORAWSKI AW. Methylene Blue and Phenol Photocatalytic Degradation on Nanoparticles of Anatase $\mathrm{TiO}_{2}$. Pol. J. Environ. Stud. 19 (4), 685, 2010.

16. SHAHBAZI A., YOUNESI H., BADIEI A. Synthesis of Organic-Inorganic Hybrid Amine Based on Nanostructured Silicate Materials and Its Application for Removal of Heavy Metal Ions from Aqueous Solution. Journal of Water \& Wastewater 23 (84), 13, 2012.

17. BARDAJEE G.R., HOOSHYAR Z., REZANEZHAD H. A novel and green biomaterial based silver nanocomposite hydrogel: synthesis, characterization and antibacterial effect. J. Inorg. Biochem. 117, 367, 2012.

18. PRASHANTH S., MENAKA I., MUTHEZHILAN R., SHARMA N. Synthesis of plant mediated silver nanoparticles using medicinal plant extract and evaluation of its anti microbial activities. Int J Eng. Sci Tech. 3, 6235, 2011.

19. AHMAD B.M., LIM J.J., SHAMELI K., IBRAHIM N.A., TAY M.Y.P., CHIENG B.W. Antibacterial activity of silver bionanocomposites synthesized by chemical reduction route. Chem. Cent. J. 6, 101, 2012.

20. HONARY S., GHAJAR K., KHAZAELI P., SHALCHIAN P. Preparation, characterization and antibacterial properties of silver-chitosan nanocomposites using different molecular weight grades of chitosan. Trop. J. Pharm. Res. 10, 69, 2011.

21. FANG C., ZHANG M. Nanoparticle-based theragnostics: integrating diagnostic and therapeutic potentials in nanomedicine. J. Controlled Release 146, 2, 2010.

22. PALIULIS D. Removal of formaldehyde from synthetic wastewater using natural and modified zeolites. Pol. J. Environ. Stud. 25, 251, 2016.

23. LINGAPPAN N., GAL Y.-S., LIM K.T. Synthesis of Reduced Graphene Oxide/Polypyrrole Conductive Composites. Mol. Cryst. Liq. Cryst. 585 (1), 60, 2013.

24. TIWARI A., AGRAWAL A. A review on challenges in synthesis of YFe2 O4 multiferroics and their possible solution in comparison to $\mathrm{BiFeO}_{3}$. Chem. Int. 2, 136, 2016.

25. REN J., GAO S., TAO L., LI H. Pb removal using mixed substrates in a constructed laboratory-scale unvegetated vertical subsurface-flow wetland. Pol. J. Environ. Stud. 25, 283, 2016.

26. KUMAR H., RANI R., SALAR R. Reverse micellar synthesis, characterization and antibacterial study of Nickel nanoparticles. In Advances in Control, Chemical Engineering, Civil Engineering and Mechanical Engineering 2010, 88-94, Athens: WSEAS. 
27. CAMARGO P.H.C., SATYANARAYANA K.G., WYPYCH F. Nanocomposites: Synthesis, Structure, Properties and New Application Opportunities. Mater. Res. 12, 1, 2009.

28. AHMED F., KUMAR S., ARSHI N., ANWAR MS., SU-YEON L., KIL G., PARK D., KOO BH., LEE CG. Preparation and characterizations of polyaniline (PANI)/ $\mathrm{ZnO}$ nanocomposites film using solution casting method. Thin Solid Films, 519, 8375, 2011.

29. CHOA Y.H., YANG J.K., KIM B.H., JEONG Y.K., LEE J.S., NAKAYAMA T. Preparation and characterization of metal: ceramic nanoporous nanocomposite powders. J. Magn. Mater. 266, 12, 2003.

30. RAY S.S., BOUSMINA M. Biodegradable polymers and their layered silicate nanocomposites: in greening the $21^{\text {st }}$ century materials world. Prog. Mater. Sci. 50, 962, 2005.

31. PANDEY J.K., KUMAR A.P., MISRA M., MOHANTY A.K., DRZAL L.T., SINGH R.P. Recent advances in biodegradable nanocomposites. J. Nanosci. Nanotechnol. 5, 497, 2005.

32. ALI B., TAHIR S., AKHTAR M.N., YAMEEN M., ASHRAF R., HUSSAIN T., GHAFFAR A., ABBAS M., BOKHARI T.H., IQBAL M. Cytotoxicity and Antimicrobial Activity of Pivalic and Benzoic AcidComplexed $\mathrm{Cu}$ and $\mathrm{Mn}$ Complexes. Pol. J. Environ. Stud. 26 (6), 2861, 2017.

33. PIOTROWSKA M., RZECZYCKA M., OSTROWSKI R., POPOWSKA M. Diversity of Antibiotic Resistance Among Bacteria Isolated from Sediments and Water of Carp Farms Located in a Polish Nature Reserve. Pol. J. Environ. Stud. 26 (1), 239, 2017.

34. QAMAR A., ASI R., IQBAL M., NAZIR A., ARIF K. Survey of Residual Pesticides in Various Fresh Fruit Crops: A Case Study. Pol. J. Environ. Stud. 26 (6), 2703, 2017.

35. PHULPOTO A.H., QAZI M.A., MANGI S., AHMED S., HAQ I.U., PHUL A.R., KANHAR N.A. Bioremediation of Oil-Based Paint from Aqueous Media by Novel Indigenous Brevibacillus parabrevis Strain NAP3 and its Toxicity Assessment. Pol. J. Environ. Stud. 26 (1), 229, 2017.

36. PODGÓRNI E., BOGUNIEWICZ-ZABŁOCKA J., KŁOSOK-BAZAN I. The Impact of Nano-Silver Doses on Microorganism-Deactivation Effectiveness in Water Circulating in a Cooling Tower Cycle. Pol. J. Environ. Stud. 24 (5), 2321, 2015.

37. TUNÇ K., HOŞ A., GÜNEŞ B. Investigation of Antibacterial Properties of Cotinus coggygria from Turkey. Pol. J. Environ. Stud. 22 (5), 1559, 2013.

38. ELSHAARAWY R.F., JANIAK C. Toward new classes of potent antibiotics: Synthesis and antimicrobial activity of novel metallosaldach-imidazolium salts. Eur. J. Med. Chem. 75, 31, 2014.

39. SHARMA S.K., AGARWAL D. Synthesis of cetylpyridiniumtribromide (CetPyTB) reagent by noble synthetic route and bromination of organic compounds using CetPyTB. Chem. Int. 1, 164, 2015.

40. SHINDY H., KHALAFALLA A., GOMA M., EED A. Synthesis, photosensitization and antimicrobial activity evaluation of some novel Merocyanine dyes. Chem. Int. 2, 114, 2016.

41. SOLANKEE A., TAILOR R. An efficient synthesis of some new chalcone, acetyl pyrazoline and amino pyrimidine bearing 1, 3, 5-triazine nucleus as potential antimicrobial and antitubercular agent. Chem. Int. 2, 189,
2016.

42. HARISH K., RENU R., KUMAR SR. Synthesis of Nickel Hydroxide Nanoparticles by Reverse Micelle Method and its Antimicrobial Activity. Res. J. Chem. Sci. 1 (9), 42, 2011.

43. ASIF M. Antiviral and antiparasitic activities of various substituted triazole derivatives: A mini. Chem. Int. 1, 71, 2015.

44. IQBAL M. Vicia faba bioassay for environmental toxicity monitoring: a review. Chemosphere, 144, 785, 2016.

45. KOWALSKA-GÓRALSKA M., ŁAWA P., SENZE M. Impact of silver contained in the Nano silver preparation on the survival of brine shrimp (Artemia salina Leach 1819) larvae. ECE (A) 18 (3), 372, 2011.

46. NAZAR N., BIBI I., KAMAL S., IQBAL M., NOUREN S., JILANI K., UMAIR M., ATA S. Cu nanoparticles synthesis using biological molecule of $\mathrm{P}$. granatum seeds extract as reducing and capping agent: Growth mechanism and photo-catalytic activity. Int. J. Biol. Macromol. 106, 1203, 2018.

47. KOLE C., KOLE P., RANDUNU K.M., CHOUDHARY P., PODILA R., KE P.C., RAO A.M., MARCUS R.K. Nanobiotechnology can boost crop production and quality: first evidence from increased plant biomass, fruit yield and phytomedicine content in bitter melon (Momordica charantia). Biotechnology 13 (37), 1, 2013.

48. ASHAR A., IQBAL M., BHATTI I.A., AHMAD M.Z., QURESHI K., NISAR J., BUKHARI T.H. Synthesis, characterization and photocatalytic activity of $\mathrm{ZnO}$ flower and pseudo-sphere: Nonylphenol ethoxylate degradation under UV and solar irradiation. J. Alloy. Comp. 678, 126, 2016.

49. BIBI I., KAMAL S., AHMED A., IQBAL M., NOUREN S., JILANI K., NAZAR N., AMIR M., ABBAS A., ATA S., MAJID F. Nickel nanoparticle synthesis using Camellia Sinensis as reducing and capping agent: Growth mechanism and photo-catalytic activity evaluation. Int. J. Biol. Macromol. 103, 783, 2017.

50. BIBI I., NAZAR N., IQBAL M., KAMAL S., NAWAZ H., NOUREN S., SAFA Y., JILANI K., SULTAN M., ATA S., REHMAN F., ABBAS M. Green and eco-friendly synthesis of cobalt-oxide nanoparticle: Characterization and photo-catalytic activity. Adv. Powder Technol. 28, 2035, 2017.

51. SRIVASTAVA S., SRIVASTAVA P., GUPTA V., JAISWAL A. Homogeneous catalytic oxidation of some polyhydric alcohols by iridium trichloride. Chem. Int. 3, 194, 2017.

52. UKPAKA C., ADAOBI S. N.-A., UKPAKA C. Development and evaluation of trans-amadi groundwater parameters: The integration of finite element techniques. Chem. Int. 3, 306, 2017.

53. ABBAS M., ADIL M., EHTISHAM-UL-HAQUE S., MUNIR B., YAMEEN M., GHAFFAR A., SHAR G.A., TAHIR M.A., IQBAL M. Vibrio fischeri bioluminescence inhibition assay for ecotoxicity assessment: A review. Sci. Total Environ. 626, 1295, 2018.

54. OGUNDIPE K.D., BABARINDE A. Comparative study on batch equilibrium biosorption of $\mathrm{Cd}(\mathrm{II}), \mathrm{Pb}(\mathrm{II})$ and $\mathrm{Zn}(\mathrm{II})$ using plantain (Musa paradisiaca) flower: kinetics, isotherm, and thermodynamics. Chem. Int. 3, 135, 2017.

55. REMYA V.R., ABITHA V.K., RAJPUT P.S., RANE A.V., DUTTA A. Silver nanoparticles green synthesis: A mini review. Chem. Int. 3, 165, 2017.

56. AMJED N., BHATTI I.A., NAZIR A., IQBAL M. Microwave Assisted Desulphurization of Coal by Photo- 
catalytic oxidation treatment. Energ. Source. Part-A. 39 (10), 1043, 2017.

57. IQBAL M., GHAFFAR A., NAZIR A., YAMEEN M., MUNIR B., NISAR N., HUSSAIN, T. Coal Desulphurization Using Gamma and Ultraviolet Radiation. Energ. Source. Part-A., 39 (11), $1109,2017$.

58. MUNIR A., SULTANA B., BASHIR A., GHAFFAR A., MUNIR B., SHAR G.A., NAZIR A., IQBAL M. Evaluation of Antioxidant Potential of Vegetables Wastes. Pol. J. Environ. Stud. 27 (2), 947, 2018.
59. LEGROURI K., KHOUYA E., HANNACHE H., EL HARTTI M., EZZINE M., NASLAIN R. Activated carbon from molasses efficiency for $\mathrm{Cr}(\mathrm{VI}), \mathrm{Pb}$ (II) and $\mathrm{Cu}$ (II) adsorption: A mechanistic study. Chem. Int. 3, 301, 2017.

60. MAJOLAGBE A.O., ADEYI A.A., OSIBANJO O., ADAMS A.O., OJURI O.O. Pollution vulnerability and health risk assessment of groundwater around an engineering Landfill in Lagos, Nigeria. Chem. Int. 3, 58, 2017. 